\title{
On the shoulders of giants/shouldering the educational burden... your one-stop shoulder shop: Bern, 22 November 2019
}

\author{
Mario Bizzini, ${ }^{1}$ Nicolas Mathieu ${ }^{2}$
}

The Swiss Sports Physiotherapy Association (SSPA) will hold its 17th annual conference on 22nd November 2019 in Bern, capital of Switzerland and home of this event since 2005 (figure 1).

The goal of SSPA has always been to organise a high-quality scientific congress featuring international high-profile speakers. Our record-breaking 2015 conferencealso the first World Congress of Sports Physical Therapy-focused on the 'Return to Play Continuum'. ${ }^{1}$ For this year's SSPA, we focus on...(check title of this piece...) yes, you guessed it! shoulder injuries with attention to diagnosis, treatment and advances in return to play advice. The shoulder-an amazing athletic weapon but also an Achilles heel one might say.

The \#sportfisio2019 edition will feature some of the most respected clinicians and researchers in the athlete's shoulder worldwide. Ann Cools, Merete Möller, Kevin Wilk, Jeremy Lewis and Suzanne Gard are five shoulder giants in the Bern conference line up. But we did not stop there; you get even more value on November 22nd with Ian Horsley, Martin Asker and Martin Hägglund!

\section{IN THIS NINTH SWISS SPORTFISIO ISSUE: A BJSM MEMBER SOCIETY SINCE 2011}

In this ninth Swiss Sports PT annual issue of BJSM, we introduce the shoulder theme with Ben Ashworth and colleagues' editorial (see page 524) on a novel test and 'all things return to play' (as Daniel Friedman (@DDFriedman) likes to say on his signature BJSM podcasts). You can read the test validation paper in the BMJ Open Sport

${ }^{1}$ Human Perfomance Lab, Schulthess Clinic, Zuerich, Switzerland

${ }^{2}$ Physiotherapy School, University of Applied Sciences Western Switzerland, Leukerbad, Switzerland

Correspondence to Mario Bizzini, Human Performance Lab, Schulthess Clinic, Zuerich 8008, Switzerland; mario.bizzini@sportfisio.ch

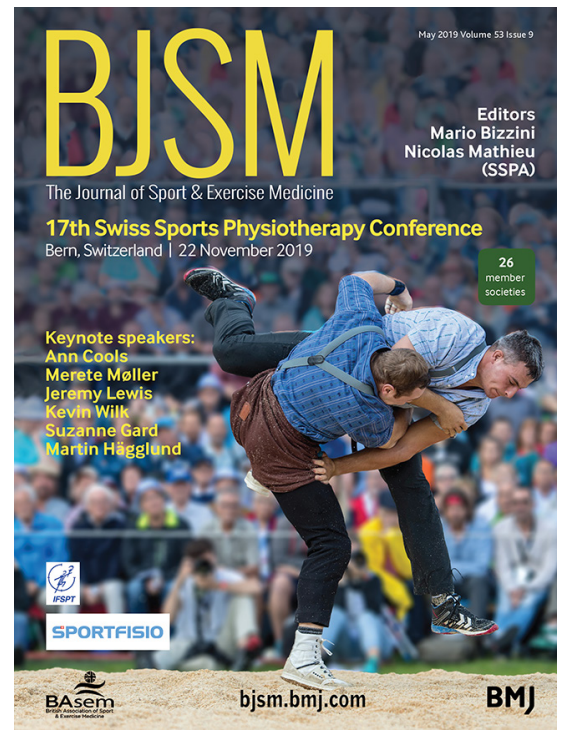

Figure 1 Top shoulder conference, Bern, 22 November, 2019.

\& Exercise Medicine. ${ }^{2}$ The stylish editorial title was inspired by Stars Wars, but instead of the often repetitive content of the last episodes of that movie franchise (IMHO), the 'Ash Test' offers an additional and novel shoulder strength test for the athlete in his/ her Return To Sport (RTS) process. RTS criteria often lack of validity, responsiveness and reproducibility: the ASH will for sure contribute to better monitor RTS of athletes in various overhead sports. You can listen to authors on a BJSM podcast here: http://ow. ly/waf830nZemA.

Three original papers in this Swiss issue by van Klij (see page 532), Werner (see page 539) and Rhon (see page 547) remind us to our 2018 conference (\#sportsuisse2018), where hip/FAI/groin topics were the major topics. And while on the subject of SSPA providing valueyou can find almost all of the conference presentations on YouTube: http://ow.ly/ lCAu30nZeGi.

The educational review by Ardern and an international cast ${ }^{3}$ is one of the pearls in this issue, and reinforces, one more time, how important it is to make a truly quality clinical decision. The authors underscore the importance of (i) a systematic search to capture the quality literature, (ii) combining quality research with quality clinical evidence and (iii) considering the feasibility of the decision. As you can well imagine, shared decision-making features prominently.

As always, keep track of the SSPA (@ SportfisioSwiss) and BJSM (@BJSM BMJ) via your favourite social media channel(s) and keep your member society abreast of what YOU want in your clinical sports medicine and physiotherapy career. That is how you find out about terrific value for sports clinicians. Such as the 'e-issues' of BJSM. They add beyond the normal 20 issues and 4 IOC-supported Injury Prevention issues. Here is the link for 2019's hip and groin e-issue: https://bjsm.bmj.com/ pages/e-edition-hip-and-groin-pain/.

Enjoy this Swiss issue of BJSM and we hope to catch you in person in Bern on 22 November 2019! Don't let your patients shoulder the burden alone!

\section{Competing interests None declared.}

Patient consent for publication Not required.

Provenance and peer review Commissioned; internally peer reviewed.

(c) Author(s) (or their employer(s)) 2019. No commercial re-use. See rights and permissions. Published by BMJ.

\section{A) Check for updates}

To cite Bizzini M, Mathieu N. Br J Sports Med 2019:53:523.

Accepted 11 March 2019

Br J Sports Med 2019;53:523

doi:10.1136/bjsports-2019-100820

\section{REFERENCES}

1 Ardern CL, Glasgow P, Schneiders A, et al. 2016 Consensus statement on return to sport from the First World Congress in Sports Physical Therapy, Bern. Br J Sports Med 2016;50:853-64.

2 Ashworth B, Hogben P, Singh N, et al. The Athletic Shoulder (ASH) test: reliability of a novel upper body isometric strength test in elite rugby players. BMJ Open Sport Exerc Med 2018;4:e000365.

3 Ardern CL, Dupont G, Impellizzeri FM, et al. Unravelling confusion in sports medicine and sports science practice: a systematic approach to using the best of research and practice-based evidence to make a quality decision. Br J Sports Med 2019;53:50-6. 